\title{
明治 39 年に行われた桐古天主堂改修工事における工事費受払の特徵 CHARACTERISTICS OF CONSTRUCTION COST RECEIPTS AND PAYMENTS FOR THE RENOVATION OF THE KIRIFURU CHURCH IN 1906
}

\author{
喜田信代*, 羽深久夫** \\ Nobuyo KITA and Hisao HABUKA
}

\begin{abstract}
The renovation of the Kirifuru Church in 1906, agreed through consultations between Yosuke Tetsukawa and the missionaries, included extension work and ceiling repairs. The renovation was estimated to cost JPY 395. 60, including the construction work for the altar. The amount received was JPY 385. 60, of which JPY 379. 56 and 4 rin were used to pay wages for craftsmen, as well as for meal, travel, and miscellaneous expenses. The church made additional payments toward material and tool costs, either directly or through Yosuke.
\end{abstract}

\section{Keywords : Meiji-era, Kirifuru-Church Renovation, Yosuke Tetsukawa, Construction cost receipts and payments} 明治期, 桐古天主堂改修工事, 鉄川與助, 工事費受払

\section{1. はじめに}

\section{1-1. 研究の目的}

鉄川與助1) は、九州地方の建築職人で、明治39年（1906）に土木 建設業鉄川組を創設し、最初の工事として、桐古天主堂改修工事 (明 治39年/1906）を施工し、以降、継続的に天主堂建築工事を竣工させ ている。

筆者らは、與助の直筆史料から、桐古天主堂改修工事（明治 39/1906)、冷水天主堂新築工事（明治40年/1907）、奈摩内天主堂新 築工事 (明治43年/1910)、今村天主堂新築工事 (大正2年/1913)、な らびに、旧長崎大司教館新築工事（大正4年/1915）の天主堂工事の 工事内容、工期、職人構成、建築工事費の内訳、請負契約関係書類、 宣教師との関わりについて明らかにしてきた ${ }^{2)}$ 。

工事費の清算方式は、契約方式と深く関わっていると考えられる。 洋風建築は、直営 ${ }^{3)}$ で出発したとされており、この他、一式請負 ${ }^{4)}$ や、実費報酬加算式5) で行われたことが明らかにされている。

そこで、本稿は、與助が鉄川組を創業直後の請負である桐古天主 堂改修工事 (明治39年/1906) の金銭受払について、直接工事費に相 当する材料費や道具代、職人手間賃などと、間接工事費に相当する 米麦代、旅費、雑費などの内容を整理し、桐古天主堂改修工事（明 治39年/1906) における與助の工事費の清算方式を明らかにする。次 に、明治期における工事費の清算方式と、與助の天主堂工事におけ る工事費の清算方式を比較検討する。換言すると、與助の工事費受 払は、既往の研究で明らかにされている工事費の清算方式と同じな のかどうかを検討することで、與助の工事費受払の特徴を明らかに することができると考える。

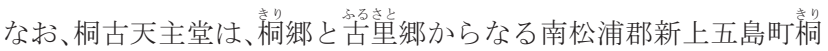

䇢里郷に建てられていた。桐古天主堂の天主堂名であるが、與助は、 自らの工事実績を記した『証明願』 ${ }^{6)}$ や『鉄川工務店工事経歴書』 ${ }^{7)}$ には「桐呇天主堂」と記しており、工事中の『手帳』(1)ら『手帳』 (3)には、「桐二滞在」、「古里二安着」、桐之浦天主堂日誌」「桐天主 堂改造金受取」、「桐ノ浦天主堂請負金」などと記している。したが って、與助は、意識して天主堂名を記したというより、地域名や通 称を記したものと考えられる。そこで、本稿では、與助が記載して いる書類名に準じて記載している ${ }^{8)}$ 。

\section{1-2. 研究の方法}

與助は、創業直後から受取金と支払金を分けて記している。具体 的には、桐古天主堂改修工事（明治39年/1906）では、『手帳』に受 取金と支払金を分けて記載しており、支払金が受取金を上回る。冷 水天主堂新築工事（明治40年/ 1907）では、『手帳』に受取金と支払 金を分けて記載しているが、材料費と屋根職人の手間賃の支払項目 がない。奈摩内天主堂新築工事（明治43年/1910）では、『手帳』と 『金銭受払簿』に受取金と支払金を分けて記載し、竣工後に『新築 工事費決算書』を整理している。『金銭受払簿』は、受払金を「御方 支払」と「私方支払」、および「工用」と「私用」に分けて記載して いる。「御方支払」は材料費と道具代、職人賃などで、「工用」は米 麦代、旅費、雑費と捉えられ、「私方支払」ならびに「私用」は與助 の個人的な費用と捉えられる。今村天主堂新築工事(大正 2 年/1913) では、『手帳』と『新築工事費豫算書』、『工場記録』と『工場簿』の ほかに『雑費記入簿』を整理している。『工場記録』と『工場簿』に は材料の見積書、注文書、契約書、送り書（納入書）があり、『雑費 記入簿』には木工部費、食料費、道具代の受払金の内訳を記載して いるが、與助が材料費を支払った記録はない。旧長崎大司教館新築
* 札幌市立大学大学院デザイン研究科 博士後期課程 $\cdot$ 修士 (学術)

** 札幌市立大学大学院デザイン研究科 教授・博士 (工学
Grad. Stud., Graduate School of Design, Sapporo City University, M.A.

Prof., Graduate School of Design, Sapporo City University, Dr. Eng. 
工事 (大正4年/1915) では、與助は天主堂工事係代人として、『支払 伝票』9) で関係者へ支払をしている。

このように、創業直後から、それぞれの工事毎の記録を整理する ことで、桐古天主堂改修工事費の受払の状況を把握することができ ると考える。

\section{2. 史料について}

桐古天主堂改修工事（明治39年/1906）の史料は、「書付」10）と、 3冊の『手帳』である。『手帳』は、旧暦明治39年1月からの日誌など のほか、桐古天主堂改修工事に関する金銭受払の記載がある ${ }^{11)}$ 。な お、『手帳』は、與助の五男・故喜一郎氏が所有するものである。 表1は、左列から、No. 、書類名、体裁、サイズ、主な記載内容、 備考をあらわしている。「書付」は、凡そ同じ記載内容で、『手帳』 (1) と『手帳』(3)に挟み込まれている ${ }^{12)}$ 。また、『手帳』(1)の「桐之浦 天主堂日誌」と、『手帳』(3)の旧暦明治39年（1906）1月から5月の日 誌（以後、桐古天主堂については明治39年の旧暦で記す）はほぼ同 じ内容で、『手帳』(1)の「桐天主堂改造金受取」と『手帳』(3)の「桐 ノ浦天主堂請負金 受取金額」は同じ内容が記載されている。
る。工期は建築工事着手前と建築工事中に分けている。日付は明治 39 年（1906）で、摘要は該当する項目の要点を示している。受取金 と支払金はそれぞれ該当する期日における受払を表している。なお、 受取金は現金で、支払金には、與助は支払っていない費用がある。 また、與助は明細ごとに記載しているが、筆者は、直接工事費に相 当する材料費、道具代、職人手間賃と、間接工事費に相当する米麦 代、旅費、雑費（郵便・文房具・消耗品費・酒代など）に分けて整 理している。

\section{(1) 受取金}

受取金は、宿老 ${ }^{14)}$ 濱口から現金で受け取っている ${ }^{15)}$ 。月別にみる と、1月は 50 円、 3 月は 50 円、 4 月は 90 円、閏 4 月は 50 円、 5 月 は 61 円、 6 月は 52 円、 7 月は 10 円、 8 月は 12 円 60 銭、 9 月は 10 円である。このうち、4月 9 日の受取金 20 円は、木婏貨支払の為の 受取金である。したがって、工事着手前の受取金は 190 円で、工事 中の受取金は 195 円 60 銭で、工事期間の受取金は 385 円 60 銭であ る。

(2) 支払金

月別の支払金は、 1 月は 61 円 98 銭、 3 月は 275 円 69 銭 4 厘、 4

表 1 桐古天主堂改修工事の工事費関係史料

\begin{tabular}{|c|c|c|c|c|c|}
\hline No & 書類名 & 体裁 & $\begin{array}{c}\text { サイズ } \\
\text { (縱 } \times \text { 横 } \times \text { 厚 }) \mathrm{mm}\end{array}$ & 主な記載内容 & 備考 \\
\hline 1 & \multirow[b]{2}{*}{ 「書付」 } & \multirow{2}{*}{$\begin{array}{l}\text { 半紙二つ } \\
\text { 折り }\end{array}$} & $122 \times 302$ & 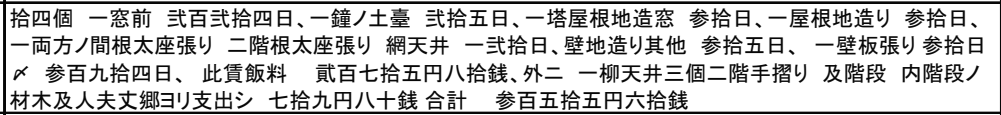 & $\begin{array}{l}\text { 『手帳』(1)に挟み込まれ、半紙 } \\
\text { の横方向に長手方向半分に記 } \\
\text { されており、毛筆書。 }\end{array}$ \\
\hline 2 & & & $121 \times 302$ & 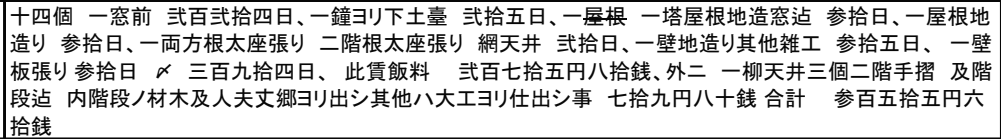 & $\begin{array}{l}\text { 『手帳』(3にに挟み込まれ、半紙 } \\
\text { の縦方向に上半分に記されて } \\
\text { おり、毛筆書。悪戯書がある。 }\end{array}$ \\
\hline 3 & 『手帳』(1) & \begin{tabular}{l|} 
表紙青色 \\
欠損
\end{tabular} & $134 \times 80 \times 50$ & $\begin{array}{l}\text { 明治39年(1906)1月14日から2月、3月、4月、閏4月14) と5月3日までの「桐之浦天主堂日誌」と、「木挽日 } \\
\text { 誌」、「桐ノ浦天主堂入金」「桐天主堂改造金受取」、「福見」、「鯛ノ浦天主堂」などが記されている。 }\end{array}$ & $\begin{array}{l}\text { No.2「書付」が挟み込まれてい } \\
\text { る。 }\end{array}$ \\
\hline 4 & 『手帳』(2) & 表紙黒色 & $131 \times 72 \times 12$ & $\begin{array}{l}\text { 明治39年(1906)9月から12月の日誌の他に、材料や買物の項目と価格、「冷水天主堂 建築費用」などが記 } \\
\text { 録されている。 }\end{array}$ & \\
\hline 5 & 『手帳』(3) & 表紙黒色 & $75 \times 107 \times 13$ & $\begin{array}{l}\text { 桐古天主堂日誌は明治39年(1906) 正月14日から18日迄である。その他、「曾根」、桐ノ浦天主堂ノ日誌」、 } \\
\text { 「冷水天主堂日誌」「桐ノ浦天主堂請負金 受取金額」「桐ノ浦天主堂エ事二テ賃銭支拂帳」、「冷水ノ部」な } \\
\text { どが記されている。 }\end{array}$ & $\begin{array}{l}\text { No.2「書付」が挟み込まれてい } \\
\text { る。 }\end{array}$ \\
\hline
\end{tabular}

凡例：(1)No. 1 と、No. 2 の「書付」は、ほぼ同じ内容である。№. 2 には、後日、書いたと思われるペンの悪戯書きがあることから、写真 1 は、No. 1 を用 いている。 (2)『手帳』は、明治 39 年(1906) 1 月 14 日 から記録され、『手帳』 (1) 『手帳』(3には重複する記述がある。(3)『手帳』は、縦書きで羁線 が入り、墨、インク、鉛筆で記され、インクや鉛筆は文字が擦れて判読の困難な部分もある。(4) 5 月 2 日から 9 月 4 日までの『手帳』の日誌は、現段階で は確認できない。(5)『手帳』は旧暦で記されている。閏 4 月などの暦があることから、本稿では、與助の史料の通り、旧暦を用いる。

\section{3. 桐古天主堂改修工事見積金}

「書付」（写真1）は、「14個の空前の工事 13)に224日、鐘より下 の土臺造りに25日、塔屋根の窓迄の地造りに30日、屋根地造り 30 日、 両方の間の根太座張り、2階の根太座張りと網天井に 20 日、壁地造り その他に 35 日、壁板張りに30日、×394日で、この手間賃と飯料は 275 円80銭」で、「他に、柳天井3個と、2階手摺り、および階段の材木及 び人夫は地元より出す約束で79円80銭で、合計 355 円 60 銭」である。 したがって、この「書付」は改修工事の人工を表し、見積書に相当 するもので、355円60銭は鉄川組の請負金と考えられる。なお、『手 帳』(2)の9月27日に小香台新製40円の追加注文があることから、桐古 天主堂改修工事の見積金は395円60銭である。

\section{4. 桐古天主堂改修工事受払金}

表 2 は、桐古天主堂改修工事における金銭受払を時系列に整理し たもので、左列から工期、日付、摘要、受取金、支払金を表してい

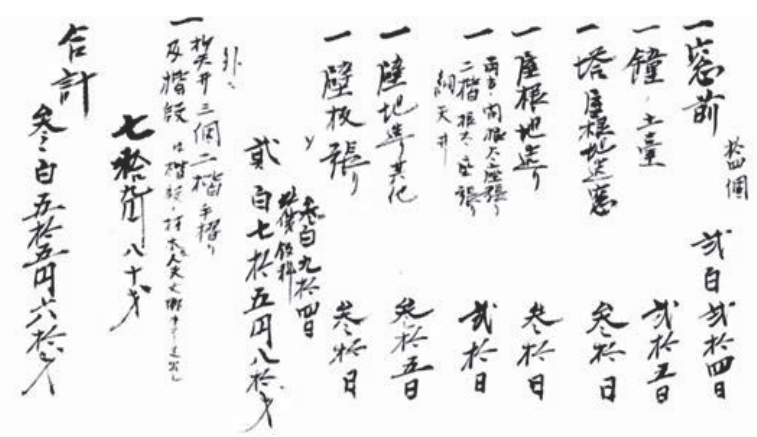

写真 1 桐古天主堂改修工事の「書付」 凡例 : 『手帳』(1)と『手帳』(3にには、ほぼ同じ内容で書かれた「書付」が 挟み込まれている。読み下しは、『手帳』(3)の「書付」を用いているが、 これには後日書きこまれたと思われる悪戯書きがあることから、写真は、 『手帳』(1)のものを用いている。 


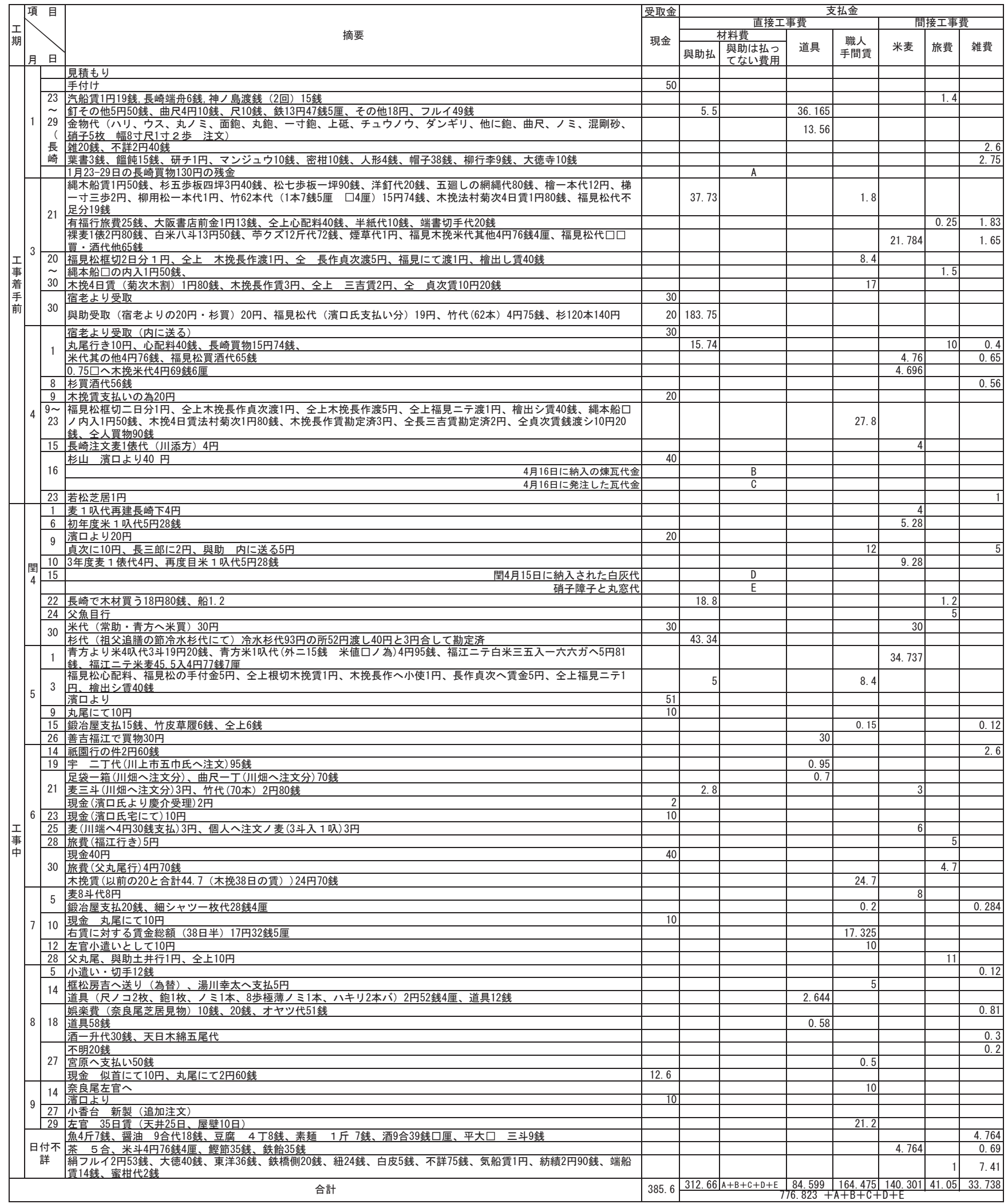

凡例：(1)本表は、史料から明らかになる、桐古天主堂改修工事着手前から竣エまでの金銭受払を示した。(2)見積金は、鉄川組改修工事費の見積金である。改 修工事の大工手間賃は飯料を含む 275 円 80 鉞と、二階及び階段工事の手間賃 79 円 80 銭の合計 355 円 60 銭と、追加工事として祭壇工事 40 円の合計 395 円 60 銭である。(3)受取金は、現金で渡されている。(4)支払金は、直接工事費と間接工事費に分けられる。(5)直接工事費は材料代、道具代、職人賃に分けられ る。(6)間接工事費は旅費、米麦代、雑費に分けられる。(7)材料費は、1月 23 日からの長崎買物代残金 A、4 月 16 日に納入された煉瓦代 B と、同日に発注さ れた瓦代 C、閏 4 月 15 日に納入された白灰代 D と、硝子障子代 6 円 99 鉞 3 厘と丸空代 $E$ があり、與助はこれらの費用を支払っていない。 
月は 69 円 60 銭 6 厘、閏 4 月は 133 円 90 銭、 5 月は 78 円 40 銭 7 厘、 6 月は 50 円 45 銭、 7 月は 46 円 80 銭 9 厘、8 月は 10 円 3 銭 4 厘、 9 月は 31 円 20 銭と、日付不詳の 14 円 35 銭 4 厘がある。

支払金は、材料費、道具代、職人手間賃と、米麦代、旅費、雑費 に分けられ、材料費は、釘・材木・竹代と、與助は支払っていない 買物代である。したがって、工事着手前の支払金は 407 円 28 銭、工 事中の支払金は 369 円 54 銭 9 厘、工事期間の支払金は 776 円 82 銭 3 厘で、この他に與助は支払っていない買物代がある。

\section{1）材料費}

(1) 釘 · 材木 · 竹代

釘・材木・竹代は 312 円 66 銭で、工事着手前は、1月 23 日から 長崎に出張した際の釷その他の買物と、3 月 21 日の材木・洋釘代、 30 日の松・竹・杉代などと、4月 22 日に木材代、30日に杉代 ${ }^{16)}$ と、工事中は 5 月 3 日に松代手付と、6 月 21 日に竹 70 本代である。

\section{(2) 與助は支払っていない材料費と買物代}

桐古天主堂工事期間の『手帳』の日誌と、工事費の記録には、買 物や、材料の納入、および発注などが記されている。與助は、請負 後、1月 23 日から 25 日まで長崎に出張し、買物をしている。4 月 4 日に、長崎で注文した品物が届き、「惣商 130 円トナル」と連絡が来 る。この記録からは、買物代金の総額も分らないまま発注はしてい る可能性が伺える。また、16 日には、煉瓦が納入され、同日、與助 は瓦を注文している。閏4月16日には白灰が納入され、硝子障子 ${ }^{17)}$ を新たに注文すると決めている。このように、買物と、納入や発注 の記録はあるが、與助が代金を支払った記録はない。そこで、與助 は支払っていない買物代は、それぞれ、A（長崎買物残金）、B（煉瓦 代)、C（瓦代）、D（白灰代）、E（硝子障子と丸空代）と表している。

工事は竣工していることから、工事工程に併せて発注され、納入 されたと考えられる。なお、長崎市において Francis. A. Groom と小山良輔との間に交された住宅の建築工事契約書 ${ }^{18)}$ では、ドア・ 空・鎧戸・鍵・ヒンジ・ボルトなどは建築主から提供されているこ とから、與助が支払っていない買物代は、教会もしくは宿老から直 接関係者に支払われたと考えられる。

\section{2）道具代}

道具代は 84 円 56 銭 6 厘である。内訳は、工事着手前は、1 月 23 日から 29 日の長崎出張の際の買物（曲尺、尺、鉄、その他と、フル イ）と、金物代（ハリ、ウス、丸）、、面鉋、丸鉋、一寸鉋、上砥、 チュウノウ ${ }^{19)}$ 、ダンギリ、他に鉋、曲尺、ノミ、混剛砂、硝子 5 枚 幅 8 寸尺 1 寸 2 歩) である。工事中は 5 月 26 日に善吉 ${ }^{20)}$ の買 物代と、 6 月 19 日に宇 2 丁、21 日に曲尺 1 丁、 8 月 14 日に道具（尺 ノコ 2 枚、鉋 1 枚、ノミ 1 本、 8 歩極薄ノミ 1 本、ハキリ 2 本バ) などを購入している。

以上の通り、工事着手前に道具を職人に渡し、工事中は道具を補 い、もしくは修理していると考えられる。

\section{3）職人手間賃}

職人は、木挽、鍛治屋、左官を雇入れており、職人手間賃は 164 円 47 銭 5 厘である。内訳は、工事着手前は 3 月 21 日の木挽貨、30 日 ${ }^{21)}$ の木婏賃、4月 9 日の木挽賃で、着手前の職人手間賃は木挽賃 である。工事中は、閏 4 月 9 日に木挽賃、5 月 3 日に木挽賃、15 日 に鍛冶屋へ支払、6月 30 日に木挽賃、7 月 5 日に鍛冶屋へ支払、12 日に煉瓦積の左官に賃金、27 日に左官へ小遣、8月 14 日に鉄川組の
湯川幸太 ${ }^{22)}$ に手間賃、27 日に宮原 ${ }^{23)}$ 一支払、9 月 14 日に奈良尾の 左官に賃金、29 日に左官に賃金である。木挽貨は、3 月、4 月、閏 4 月、 5 月、 6 月と毎月精算している ${ }^{24)}$ 。左官には工事終了後に清算し ている。また、鉄川組は家族と雇入れた職人で構成されるが、8月 14 日の湯川幸太への支払の他に、家族への支払は確認できない。 職人手間賃は、日給で、與助は、木挽と鍛冶屋、左官の手配と管理 を行ない、職人に手間賃を渡している。

\section{4）米麦代}

米麦代は 140 円 30 銭 1 厘である。内訳は、工事着手前は、3 月 21 日に裸麦一俵、白米八斗・苧クズ代・福見木挽米代などと、4 月 1 日に米代と、木挽米代、4月 15 日に麦 1 俵代である。工事中は、閏 4 月 1 日に麦 1 叭代、 6 日に米 1 叭代、 10 日に麦 1 俵代 - 米 1 叭代 などと、30日に米代、5 月 1 日に米麦代、6月 21 日に麦代、25日に 麦代、 7 月 5 日に麦代、日付不詳の米代などがある。工事着手前と 工事中の米麦代を比較すると、凡そ $1: 3$ となることから、工事着手 後は着手前の 3 倍に相当する職人が従事したと考えられる。なお、 『手帳』(1) 3 月 21 日の「木挽ノ食料八濱口ニ依頼ス」の記載から、 木挽の食糧は別に賄われていることが分かる ${ }^{25)}$ 。

\section{5）旅費}

旅費は 41 円 5 銭である。内訳は、工事着手前の 1 月の長崎出張の 際の汽船賃などと、3 月 21 日の有福行旅費、3 月 30 日の縄本船 $\square$ の 内入 ${ }^{26)} 、 4$ 月 1 日は丸尾行き費用である。工事中の閏 4 月 22 日は長 崎行き、24 日の父の魚目行き、 6 月 28 日福江行き、30 日父の魚目 行き、 7 月 28 日に父と與助の旅費と、日付不詳の船賃である。工事 期間中は、長崎への出張の他、上五島の鉄川組の拠点である魚目町 丸尾鄉や、中五島の桐古天主堂工事現場の近くの有福島や、下五島 の福江への船賃であることから、工事の間は五島列島と長崎市内を 往来し、旅費はその費用であることが分る ${ }^{27) 。}$

\section{6) 雑費}

雑費は 33 円 73 銭 8 厘で、郵便・文房具・消耗品費・酒代である。 内訳は、工事着手前は、1 月の長崎出張中の買物（葉書、饂飩、マ ンジュウ、密柑、人形、帽子、柳行李、大徳寺など）と、3 月 21 日 の大阪書店前金 ${ }^{28)}$ や、心配料 ${ }^{29)}$ 、半紙代、端書切手代などと、酒代 他、4月 1 日の心配料と酒代、4月 8 日に酒代、4 月 23 日に若松芝 居見物料 ${ }^{30)}$ などである。工事中は、閏 4 月 9 日に與助の家に送り、 5 月 15 日に竹皮草履、 6 月 14 日に祇園行き、7 月 5 日に綿シャツ、 8 月 5 日切手代など、 8 月 18 日に芝居見物と酒代、27 日の使途不明 20 銭、日付不詳の食糧費（魚 4 斤 7 銭、奨油 9 合代 18 銭、豆腐 4 丁 8 銭、素麺 1 斤 7 銭、酒 9 合 39 銭 $\square$ 厘、平大 $\square$ 三斗 9 銭や茶 5 合、鉄飴 35 銭)、生活雑貨など（絹フルイ、大徳、東洋、鉄橋側、 紐、白皮、不詳 75 銭、紡績、端船賃、蜜柑代）である。雑費には大 阪に注文した書籍や切手代、芝居見物などの娛楽費や酒代の他、與 助の出張時の嗜好品代や家族への土産代などと、私用とみなされる 費用や遊興費も含まれている。

\section{5. 桐古天主堂改修工事における工事費の精算方法}

表 3 の桐古天主堂改修工事における月別の金銭受払は、左列から 工事期間、摘要、受取金、支払金を整理している。工事期間は、工 事着手前と工事中で、摘要は該当する月別の要点を表している。 受取金は現金で、支払金は直接工事費（材料費、道具代、職人手 
間賃）と、間接工事費（米麦代、旅 費、雑費）に分けている。以下 に、受取金と支払金の関係につ いて検討する。

\section{(1) 受取金と支払金}

工事期間における受取金は 385 円 60 銭で、支払金は 776 円 82 銭 3 厘で、支払金が 391 円 22 銭 3 厘多くなる。この他に、與 助は支払っていない買物代があ る。

與助は、『手帳』に工事の記録 を記しているが、工事請負の後 に、直接山に入り、山主と交渉 し、材木を買付けている。また、 材料費については、釷・材木 · 竹代は宿老から受取り、與助が 関係先に支払っているものと、 支払っていない材料費（煉瓦. 瓦・白灰・硝子障子・丸空など） があるが、施工に必要な材料費 の支払は、教会が行ったと考え るのが順当と思われる。道具代 は教会からの受取金は確認でき ないが、工事着手前に職人の道 具を揃えて、工事に備えたもの と考えられ、手付金を充当した 可能性が考えられる ${ }^{31)}$

請負は鉄川組の飯料を含むも ので、祭壇の追加工事費は、そ

の後、修正されていないことから当初の見積で施工されたと考えら れる。

鉄川組は桐古天主堂改修工事の着工年である明治 39 年 (1906) に 創業しており、建設業者として資金的に潤沢とは考えにくい。そこ で、與助は、着手金として手付を受取り、材料費である材木や、組 の米代や、鉄川組の拠点の丸尾の費用、娛楽費まで含めた雑費を施 主からその都度受取り、支払に充てたと考えられる。與助が支払っ ていない煉瓦、瓦、白灰、硝子障子・丸空などの費用は、與助を通 すことなく、関係者に教会から支払われたと考えられる。

このような受払の内訳から、與助の受取金 385 円 60 銭は、職人手 間賃 164 円 47 銭 5 厘と、米麦代 140 円 30 銭 1 厘と、旅費 41 円 5 銭、雑費 33 円 73 銭 8 厘の合計 379 円 56 銭 4 厘に充てられたと考え られる ${ }^{32)}$ 。

\section{（2）桐古天主堂改修工事請負と工事費の流れ}

図 1 は、桐古天主堂改修工事費の受払の流れを示している。

工事費は、直接工事費にあたる材料費、道具代、職人手間賃と、 間接工事費にあたる米麦代、旅費、雑費である。材料費は、與助が 山主等と交涉し、直接買付けた材木や竹代 312 円 66 銭と、與助は支 払っていない買物代 A と煉瓦代 B、瓦代 C、白灰代 D、硝子障子・丸 空代 $\mathrm{E}$ がある。道具代 84 月 59 銭 9 厘は、最初に大工道具を渡した
ものと考える。職人手間賃 164 円 47 銭 5 厘は、與助が、木挽、左官 の作業を管理し、支払っている。

また、米麦代 140 円 30 銭 1 厘、旅費 41 円 5 銭、雑費 33 円 73 銭 8 厘は、與助が支払っている。

\section{（3）「桐ノ浦天主堂請負金 受取金額」における與助の勘定}

写真 2 「桐ノ浦天主堂請負金 受取金額」は、與助が、受取金の 支払内容を記したもので、「第 1 回目勘定」は 4 月 8 日迄で 130 円で ある。その内訳は 1 月の手付 50 円、福見松代 19 円、竹 62 本 4 円 75 銭、木挽米代其他 4 円 76 銭 4 厘、雑費に相当する心配料や酒代 1 円 5 銭、長崎買物代 15 円 74 銭や、丸尾の費用 30 円、現金 4 円 69 銭 6 厘であり、表 3 の 1 月から 4 月 1 日迄の宿老よりの受取金 130 円の明細であることが判る。「第 2 回目勘定」は 4 月 9 日から 5 月 3 日迄で 51 円である。その内訳は長崎行きの 20 円、若松芝居見物の 1 円、青方一米買に行く為の常助の受取 30 円であり、表 2 の濱口よ りの 20 円と、米代に符合寸る ${ }^{33)}$ 。 5 月 9 日以降の「第 3 回目勘定」 は 94 円 60 銭で、木挽貨、鍛冶屋へ支払、左官に賃金や小遣と、鉄 川組の湯川幸太等の職人賃に充てられている。このような受払から、 與助は、工事に必要な費用を、その都度注文者である教会や、宿老 から受け取っていると考えられる 


\section{6. 天主堂建築工事における工事費清算の方法}

表 4 は、桐古天主堂改修工事から旧長崎大司教館新築工事にお ける建築工事と受払の概要を表している。表は左列の下段方向に 工事概要を表し、右方向に古い順から桐古天主堂改修工事（明治 39 年/1906)、冷水天主堂新築工事（明治 40 年/1907）、奈摩内天 主堂新築工事（明治 43 年/1910)、今村天主堂新築工事（大正 2 年/1913)、旧長崎大司教館新築工事 (大正 4 年/1915) を表してい る。

\section{（1）工事費清算の推移}

1）冷水天主堂新築工事（明治 40 年/1907）

冷水天主堂新築工事は、桐古天主堂改修工事の最中に、宣教師 から依頼され、煉瓦造と木造を検討したうえで、木造で新築する ことに決まり、「木挽の不足の件については神父（曽根で病床中の 神父）が補う」と仲裁を受け ${ }^{35)}$ 、大工木挽手間共 400 円、その内 大工の費用 325 円、木挽の費用 75 円で、桐古天主堂改修工事の䇋 工直後に着手している。

工事費は受取金 335 円 61 銭 2 厘で、支払金は 321 円 12 銭 2 厘 である。工事着手前に道具一年分を渡しているが、材木代と瓦代 と屋根職人賃、および次亜燐 1 本代四十銭、金剛砂代は與助は支 払っていない。

2) 奈摩内天主堂新築工事（明治 43 年/1910)

奈摩内天主堂新築工事は、與助の野崎島での木材買付けから始 まっている。工事費は決算金額 6,720 円 86 銭 9 厘で、その内訳は、 材木之部、石之部、煉瓦之部、左官之部、木工之部、塗物之部、硝 子之部、金物之部、鋼鉄天井の材料費、職人手間賃、運搬費と、諸 道具ノ部、職人賄雑費、諸雑費の 12 項目に分けて整理している。瓦 代は、左官之部で決算されていることから、屋根工事は左官が行っ たものと考えられる。請負金は木工之部の大工・木婏手間賃 1,560 円で、木挽手間賃を含んでいる。また、與助は、工事費を「御方支 払」と「私方支払」、および「工用」と「私用」に分けており、「御 方支払」は材料費、道具代、職人手間賃で、「工用」は米麦代、工事 雑費などである。「私方支払」および「私用」は與助の個人的な費用 と考えられる。工事終了後に大久保金物店への支払金 5 円を受取っ ている。與助は工事費を教会から受取、その都度、支払に充ててい る。

\section{3）今村天主堂新築工事（大正 2 年/1913）}

今村天主堂新築工事は、奈摩内天主堂新築工事竣工後に、鉄川組 一同が、福岡県の今村天主堂工事現場に移動し、工事に着手してい る。今村天主堂新築工事は、地盤工事に予想を超える事態があり、 基礎工事の材料の追加の発注を繰返している。

工事費は、假設工事費、土工事費、煉瓦工事費、石工事費、木工 事費、金物工事費、屋根工事費、漆喰工事費、塗物工事費、硝子工 事費、雑工事費、雑費の 12 項目に分けて材料費と職人手間賃を合算 して見積り、『新築工事費豫算書』は21, 723 円 33 銭である。その後、 基礎工事などの追加工事により、工事着手後に『工場記録』で 22,077 円 61 銭 5 厘と修正している ${ }^{36)}$ 。また、『雑費記入簿』には、材料費 と職人手間賃以外の支出を、木工部費、食料其他、道具費に分けて 記帳している。木工部費は鉄川組の職人賃と木挽賃のほか、丸尾一 の送金、出張交通費 - 宿泊費、電報・郵便の通信費、職人及び家族 の衣服費、芝居見物や温泉の娛楽費・病院代が含まれている。なお、

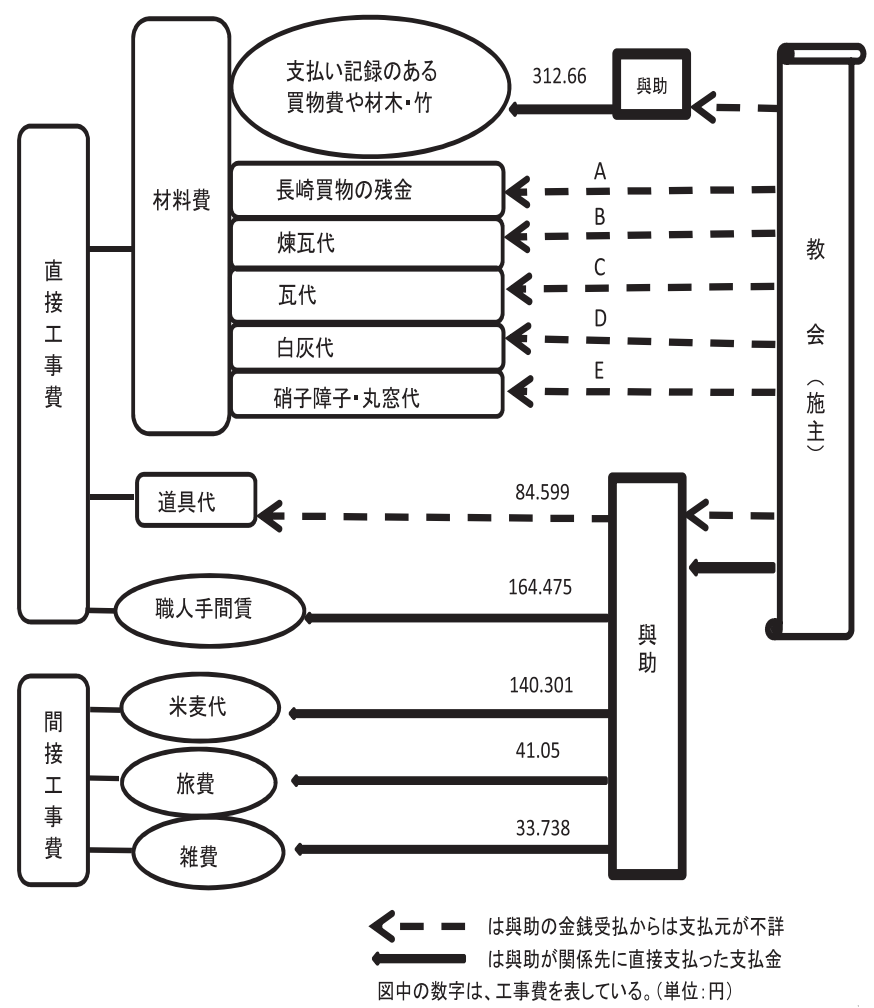

図 1 桐古天主堂改修工事費の受払の流れ

凡例：與助は支払っていない買物代は、便宜的に ABCDE としている。A は 1 月 23 日から 29 日の長崎買物の残金、Bは 4 月 16 日に納入した煉瓦代、C は発注した瓦代、Dは閏 4 月 15 日に納入した白灰代、 $E$ は硝子障子代と丸 悹代である。

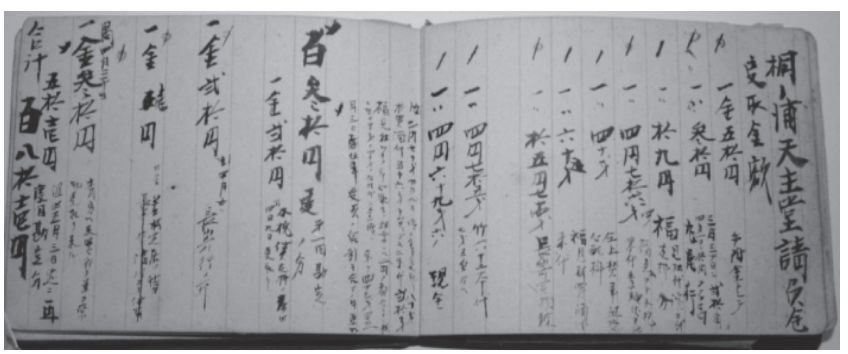

写真 2 『手帳』(3)「桐ノ浦天主堂請負金 受取金額」

しくは、補修用としての支払と考えられる。木工部費、食料其他、 道具費を併せて受取金は 3,771 円である ${ }^{37}$ 。

與助は、工事着手前に、地質調查を行い、大杉柱を買付け、松杭 木を発注し、さらに杭木を追加注文し、洋釷を発注し、地盤改良の ため焼過煉瓦とセメント、火山灰を買付け、工事中は、瓦、石材、 木材の発注や契約を繰返している。なお、木材は業者から與助が直 接買付け、瓦代も與助が支払っているが、煉瓦代と石材代、および 地盤改良の材料費と洋釷代は、與助は支払っていない。この他、與 助は、材料と施工に従事寸る職人を手配し、石工、煉瓦工、左官の 職人手間賃は與助を通して支払われている。

したがって、與助が業者から直接買付けた木材代と瓦代は、與助 を通して支払われているが、與助は支払っていない費用は、教会か ら直接、関係先に支払われたと考えられる。 
4）旧長崎大司教館新築工事（大正 4 年/1915）

旧長崎大司教館新築工事は、明治 43 年（1910）から検討され、大 正 2 年（1913）に着手している。司教館工事は、司教館の基礎工事 ともなる地下室 ${ }^{38)}$ 工事と、司教館裏手の整地作業で出来た土地に、 小使住宅と便所並びに湯場を新築する工事を含んでおり、司教館本 館を新築する工事である。

與助は旧長崎大司教館の天主堂工事係代人として従事し、発注者 の立場で請負業者と、見積書、契約証、仕様書、請負者心得、一式 請負人心得書と証書式、建築材料納方請負人心得書と証書式、建築 材料運搬請負契約証、注文書などの請負契約関係書類を取交し、工 事を管理している。工事実績のない業者からは、保証金と保証品を 預かり、工事終了後には、保証金を返している。
工事費は、仮設工事、運搬工事、煉瓦工事、石工事、木工事、金 物工事、瓦工事、塗装工事、硝子工事、雑工事、左官工事の 11 の工 事項目 ${ }^{39)}$ と、その他の費用である便所・湯場・門番所、小使住宅、 廊下・階段工事、保証金、神父、弯具庫/御像台と、妻の卜サに渡し た費用 ${ }^{40)}$ に分けて整理しており、教会は「支払伝票」により、材料 費や職人手間賃、建築材料納方と運搬請負の費用を業者に支払って いる。與助の代人としての報酬は、史料からは不詳である。

\section{（2）工事費清算の経緯}

桐古天主堂改修工事（明治 39 年/1906）では、鉄川組の請負金は 最初に決めている。材料費のうち與助が直接、山主などと交涉し、 買付けている材木代などは、與助が直接現金で支払、その他の煉瓦、 瓦、白灰、石材、金物や硝子障子などは、発注を與助が行い、支払

表 4 桐古天主堂改修工事から旧長崎大司教館新築工事における建築工事受払の概要

\begin{tabular}{|c|c|c|c|c|c|}
\hline 工事名 & & & & & 旧長崎大司教館工事 \\
\hline 工事概要 & 恫古大王堂改修工事 & 冷水大王棠新染工事 & 会摩内大王堂新染工事 & 今村大王棠新染工事 & 本館工事 \\
\hline 工事種別 & 天井改修·増築 & 新築 & 新築 & 新築 & 新築 \\
\hline 構造 & 木造を一部煉瓦造に & 木造 & 煉瓦造 & 煉瓦造 & 煉瓦造 \\
\hline 規模/階数 & $200 \mathrm{~m}^{2} / 2$ 階 & $260 \mathrm{~m}^{2} / 2$ 階 & $480 \mathrm{~m}^{2} / 2$ 階 & $495 \mathrm{~m}^{2} / 2$ 階 & $825 \mathrm{~m}^{2} /$ 地下 1, 地上 3 \\
\hline \begin{tabular}{|l|l|l} 
I前打合 \\
\end{tabular} & M39.1.14 & M39.3.19 & M41 & M43 & $\mathrm{M} 43$ \\
\hline 耚着手 & M39.3頃 & M39.12.15 & M42.4 & M45.2 & T2.の入梅より前 \\
\hline 程竣工 & M39.11.10頃 & 不詳(M40.7頃) & M43.8.17 & T2.9.18頃 & $\mathrm{T} 4.4$ \\
\hline 建 請負金 & $\begin{array}{l}355 \text { 円 } 60 \text { 錢（大エ·木 } \\
\text { 挽手間、飯料含） }\end{array}$ & \begin{tabular}{|l|} 
大工木挽手間共400円 \\
(大工325円、木挽75円) \\
\end{tabular} & 大工·木挽手間賃 $1,560 円$ (決算) & \begin{tabular}{|c|} 
大エ・木挽手間賃4,362円50銭 \\
(予算)
\end{tabular} & 鉄川與助の代人手数料(金額不詳) \\
\hline 築追加 & 祭壇工事40円 & & 祭壇工事 & 基礎工事に追加工事発生 & \\
\hline 工予算書 & & & & 21,723円33銭 & \\
\hline 事受取金 & $385 \mathrm{円} 60$ 銭 & 335円61銭2厘 & 4372円62銭 & 不詳 & \\
\hline 費支払金 & 776円82銭3厘 & 321円12銭2厘 & 3654円39銭 & 不詳 & 16,433 円 22 銭 \\
\hline 決算金 & 776円82銭3厘 & 721円12銭2厘 & 6,721円33銭 & 凡3万円を超える金額 & 16,433 円 22 錢 + 鉄川與助の代人手数料 \\
\hline $\begin{array}{l}\text { 工事着手前の } \\
\text { 発注など }\end{array}$ & \begin{tabular}{|l|} 
大エに道具箱一年分を \\
渡す。杉材を買付。
\end{tabular} & $\begin{array}{l}\text { 大エに道具箱一年分を } \\
\text { 渡す。松、杉、檜を買 } \\
\text { 付。 }\end{array}$ & $\begin{array}{l}\text { 野崎島で奈摩内用木材買付。煉瓦を } \\
\text { 発注。 }\end{array}$ & $\begin{array}{l}\text { 地質調盃。不材の買付。松杭不 } \\
240 \text { 本注文。焼過煉瓦5万個、セ } \\
\text { ×ント120樽、火山灰150俵、並 } \\
\text { 煉瓦22万個、上煉瓦 } 11 \text { 万個、石 } \\
\text { 灰、洋釘を注文。 }\end{array}$ & 煉瓦と材木の発注。 \\
\hline 支払金の特徵 & $\begin{array}{l}\text { 煉瓦代、石灰代、瓦 } \\
\text { 代、硝子障子·丸空代、 } \\
\text { 長崎買物の残金は、與 } \\
\text { 助は支払っていない。 }\end{array}$ & \begin{tabular}{|l|} 
材木代と、瓦代、次亜燐 \\
1 本代四十銭、金剛砂代 \\
と、屋根職人手間賃は \\
與助は支払っていない。
\end{tabular} & $\begin{array}{l}\text { 支払金は、「御方支払」(材料費、道具 } \\
\text { 代、職人手間賃)と、「工用」(米麦代、 } \\
\text { 工事雑)費)と、與助の私的費用である } \\
\text { 「私方支払」と「私用」に区分されてい } \\
\text { る。 } \\
\end{array}$ & $\begin{array}{l}\text { 地質調査費と、煉瓦代と石材 } \\
\text { 代。ひ地盤改良の材料代 } \\
\text { と、その他の材料代と洋釘代、 } \\
\text { および職人手間賃は、與助は支 } \\
\text { 払っていない。 }\end{array}$ & $\begin{array}{l}\text { 教会は、「支払伝票」で、材料費や職人手間賃、建築材料納方 } \\
\text { と運搬請負の費用を業者に清算している。橆助は、工事係代 } \\
\text { 人として、支払伝票」を確認している。 }\end{array}$ \\
\hline \begin{tabular}{|l} 
工事費に関す \\
る記載のある \\
書類
\end{tabular} & 『手帳』、「書付」 & 『手帳』 & $\begin{array}{l}\text { 『手帳』、『金銭受拂簿』、『新築工事費 } \\
\text { 決算書』 }\end{array}$ & $\begin{array}{l}\text { 『手帳』、『新築工事費予算書』、 } \\
\text { 『工場記録』、『雑費記入簿』 }\end{array}$ & 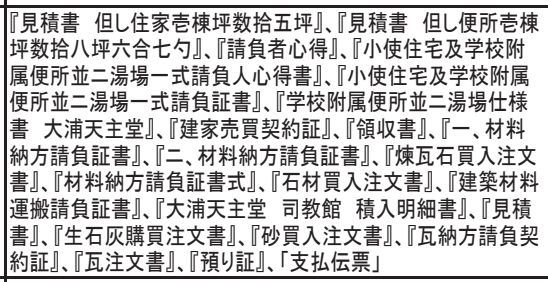 \\
\hline 工事項目 & $\begin{array}{l}\text { 大工工事、木挽工事、 } \\
\text { 左官工事 }\end{array}$ & 大工工事、木挽工事 & $\begin{array}{l}\text { 材木之部、石之部、煉瓦之部、左官之 } \\
\text { 部、木工之部、塗物之部、硝子之部、 } \\
\text { 金物之部、鋼鉄天井の材料費、職人手 } \\
\text { 間賃、運搬費と、諸道具/部、職人賄 } \\
\text { 雑費、諸雑費 }\end{array}$ & $\begin{array}{l}\text { 假設工事、土工事、煉瓦工事、 } \\
\text { 石工事、不事、金物工事、屋 } \\
\text { 根工事、渗喰工事、叙物工事、 } \\
\text { 硝子工事、雑工事、雑費 }\end{array}$ & $\begin{array}{l}\text { 仮設工事、運搬工事、煉瓦工事、石工事、木工事、金物工事、 } \\
\text { 瓦工事、塗工装工事、硝子工事、雑工事、左官工事、便所·湯場. } \\
\text { 門番所、小使住宅、廊下·階段工事、保証金、神父、枿具庫/御 } \\
\text { 像台、妻の卜サに渡した費用 }\end{array}$ \\
\hline 備考 & $\begin{array}{l}\text { 11工事着手前に、工事 } \\
\text { 内容と、請負金を「書 } \\
\text { 付」整理している。(2) } \\
\text { 左官は、煉瓦工事と、 } \\
\text { 洨喰工事をしている。 }\end{array}$ & $\begin{array}{l}\text { (1)工事中の受取金には肥 } \\
\text { 後調査費150円を含む。 }\end{array}$ & 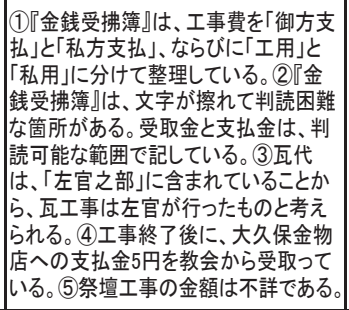 & 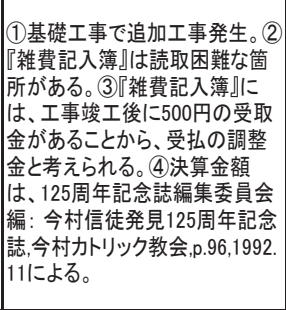 & $\begin{array}{l}\text { (1)旧長崎大司教館新築工事は、司教館本館工事の前に、司 } \\
\text { 教館の基礎工事ともなる地室工事と、司教館裹手の傾斜地 } \\
\text { を造成し、整地作業で新たにに出来た土地に、小使住宅(建坪15 } \\
\text { 坪)と便所並びに湯場(建坪18坪6合7勺)を新築する工事を含 } \\
\text { んでいる。この他、建屋1棟の解体工事を含んでいる。璵助 } \\
\text { の、天主堂工事係代人としての手数料は、現在の処は、不詳で } \\
\text { ある。 }\end{array}$ \\
\hline
\end{tabular}

凡例：(1)本表は、桐古天主堂改修工事から旧長崎大司教館新築工事までの、建築請負の概要と、建築工事費の受払について整理している。(2)建築工事費 は、桐古天主堂改修工事から今村天主堂新築工事は現金の受払で、旧長崎大司教館新築工事は、「支払伝票」で清算されている。(3)工事項目は、奈摩内天 主堂は「新築工事費決算書」、今村天主堂新築工事は「新築工事費豫算書」に整理したもので、旧長崎大司教館新築工事は「支払伝票」に、漢数字と工事 内容を記している。漢数字は、田中豊太郎編（辰野金吾、妻木頼黄博士、三橋四郎の閲覧）：和洋建築工事仕様設計實例 上・下：工業書店建築書院，1905、 および 1908 の出典史料に記載されている漢数字と工事項目が一致することから、與助は、本書を参考にしたものと考えられる。 
を教会が直接行っていると考えられる。また、與助は工事着手前に 道具を鉄川組職人に渡している。煉瓦工、左官、石工などへ渡寸賃 金は、教会から受取、與助を通して職人に支払われている。

冷水天主堂新築工事（明治 40 年/1907）では、最初に鉄川組と木 婏の請負金を決め、與助は受取金で杉材を買付けている。この他に、

瓦代と次业燐 1 本代四十銭、金剛砂代と、屋根職人の手間賃は與助 は支払っていないことから、教会が直接、関係先に支払ったと考え られる。

奈摩内天主堂新築工事（明治 43 年/1910）では、請負金は大工木 挽手間貨 1, 560 円で、工事費を「御方支払」と「私方支払」、もしく は、「工用」と「私用」に分けている。「御方支払」は材料費、道具 代、職人手間賃で、「工用」は米麦代、工事雑費などで、「私方支払」 と「私用」は與助の個人的な費用と捉えられる。與助は、工事費を 教会から受取、支払に充てている。

今村天主堂新築工事 (大正 2 年/1913) では、請負金は大工・木挽 手間賃 4, 362 円 50 銭の予算である。與助は、業者から直接買付けた 木材代と、瓦代を支払っているが、その他の費用は、教会から直接、 関係者に支払われたと考えられる。石工、煉瓦工事、左官の職人手 間貨は與助を通して支払われている。

旧長崎大司教館新築工事 (大正 4 年/1915) では、與助が天主堂工 事係代人として、「支払伝票」で確認し、教会が材料や施工、工手間 や材料納方、運搬請負などの費用を支払っている。

このように、天主堂建築工事における工事費は、最初に鉄川組の 請負金を決め、工事着手前に大工に道具を渡し、與助が直接、関係 者と交渉して現場で買付けた材木代や、職人手間賃などは與助を通 して支払い、その他の材料費は、教会から直接関係先に支払われた と考えられる。なお、教会は、「支払伝票」を用いることで、現金の 受払による間違いを防ぐことができたと考えられる。

與助は、材料を安く購入し、職人の手配や管理をして手数料を取 る訳ではない。しかし、材料や職人を與助が手配することで、間違 いを減らし、工事は管理しやすく、工事費の未払いなどのトラブル は避けられるといえる。

\section{7. 明治期に行われていた工事費の清算方式における桐古天主堂改修 工事の工事費清算方式の位置付け}

直営方式は、建築主が工事を元請業者に依頼せず、自ら労務、材 料、施工機械類の調達と施工管理を行う方式である。一式請負は、 建築主は棟梁に施工を一任する契約で、建築代金の総額を請負代金 として定め、建築工事は下請業者に請負わせる方式であり、工事代 金は一式で、その内訳が分らないことから不正があっても見つけに くい欠点がある。このように一式請負の欠点も指摘されているが、 明治 20 年 (1887) 当時には、凡そ $80 \%$ が一式請負に切り替わって いる ${ }^{41)}$ 。なお、英吉利法律学校の一式請負契約書では、第十九條 請 負人八左項二従七建築師ノ承諾書ヨ得テ金圓ヨ受取ルコトヨ得ルモ ノトス則于 側石迄落成ノ後 請負金高 五分一、二階梁置渡ノ後 全 五分ノ一、小屋梁配置ノ後 全五分ノ二、皆落成ニテ 全 五 分ノ一、但シ双方協議ノ上建築師二於テ相當卜認ムルトキハ右金圓 受取期限习伸縮スルコトアルベシ」と、工事の進捗によって工事費 を受取ることが決められている ${ }^{42)}$ 。また、実費報酬加算式は、工事 の施工者は注文者の委任を受け、注文者に代わって工事を施工し、
これに要した費用は、「利益をこめない実際の費用だけを建築主に負 担せしめ、これと同等に従来の利益に替えて、自分の労務に対して 適当なる報酬を建築主に出して貴う」方式で、「請負人は手数料を得 て、損失を招かしむることなく」と、その都度注文者から受取、工 事の進捗を図る方式である ${ }^{43)}$ 。

與助は、明治期に魚目水産学校新築工事 (明治 40 年/1907)、なら びに若松村立尋常小学校新築工事（明治 45 年/1912）を施工してい $3^{44)}$ 。後者の書類には「若松村立尋常小学校 一式請負人心得書」 があることから、工事は一式請負で施工されたと考えられるが、工 事費の受払に関寸る史料は未確認であり、不詳である。

桐古天主堂改修工事（明治 39 年/1906）は、最初に工事工程や見 積金を示して、大工手間賃と米麦代などを含めた鉄川組の請負金を 決めている。材料費の内、與助が直接買付けた木材は、教会から受 取、與助を通して支払っている。また、煉瓦、瓦、白灰、石材、金 物や硝子障子などは、與助が発注しているが、支払はしておらず、 與助は職人の手配や管理を行い、手間賃は支払っているが、その管 理料は受取っていない。このほか、間接工事費にあたる米麦代、旅 費、雑費に至るまで教会にその内訳を伝え、その都度費用を受取り 支払に充てている。

このような桐古天主堂改修工事(明治 39 年/1906)の金銭受払は、 直営でも、一式請負でもないと考えられる。最初に工事工程や見積 金を示して、大工手間賃と米麦代などの鉄川組の請負金を決め、支 払の内訳を施主に明示したうえで、その都度受取っている点は、実 費報酬加算式と類似しているが、材料費などに與助が支払っている 費用と、施主が支払ったと考えられる費用があること、予算書や支 払明細書、決算書や領収書が完備されていないことから、実費報酬 加算式とはいえない。

明治 37 年（1904）は日露戦争が勃発し、明治 40 年（1907）頃は 株価が暴落し、大正 5 年 (1916) は第一次世界大戦が始まっており、 物価は大きく変動している ${ }^{45)}$ 。建築工事は、長い工事の期間を要す るが、並行して起こる物価の変動に際しても、教会から直接工事費 が清算されることで、與助は損失の不安が少なくなると考えられる。

\section{8. まとめ}

桐古天主堂改修工事（明治 39 年/1906）は、鉄川與助が教会から 依頼されたもので、天井改修に伴う増築工事で、改修工事の内容は 宣教師との打合によるものであった。與助は、最初に工事工程や見 積金を示して、大工手間賃と米麦代などの鉄川組の請負金を決めて いる。桐古天主堂改修工事費は、支払の内訳を施主に明示したうえ で、その都度受取っている。

桐古天主堂改修工事の見積金は、祭壇工事を含めて 395 円 60 銭で ある。受取金は 385 円 60 銭であり、與助は、受取金を職人手間賃と 米麦代、旅費、雑費の 379 円 56 銭 4 厘に充てている。この他に、教 会は材料費を直接、もしくは與助を通して関係者に支払っていると 考えられる。桐古天主堂改修工事費は、支払合計 776 円 82 銭 3 厘と、 教会から直接支払われた材料費などの合計である。

與助は鉄川組創業直後の桐古天主堂改修工事（明治 39 年/1906） で行った、始めに鉄川組の請負金を決め、工事着手前に大工に道具 を渡し、與助が直接関係者と交涉して現場で買付けた材木代や、職 人手間賃などは與助を通して支払い、その他の材料費は教会から直 
接関係先に支払う方法をその後の天主堂新築工事でも行っていた。 與助は、材料を安く購入し、職人の手配や管理をしても、手数料 を取る訳ではない。しかし、與助が、材料や職人を手配することで、 間違いを減らし、工事は管理しやすく、工事費の未払いなどのトラ ブルは避けられるといえる。また、材料費など、工事費は、教会か ら直接、清算されることで、工事期間中の物価の変動に対しても、 與助の損失の不安が少なくなるという利点があった。

\section{謝辞}

史料の提供者である故鉄川喜一郎氏に心から感謝致します。

\section{注}

1）鉄川與助（1879～1976）は、明治 12 年（1879）長崎県南松浦郡魚目村似 首郷 (現長崎県南松浦郡新上五島町丸尾鄉) に大工鉄川與四朗（生年不詳 〜1939）の 6 男 1 女の長男として生まれる。長崎県南松浦郡榎津尋常小学 校卒業後、稼業の大工を手伝い、明治後期から昭和期にかけて、地元であ る長崎県五島や九州本土において、洋風建築である教会建築や学校建築、 寺院、一般

建築を多数、設計、および施工している。また、明治 39 年 (1906) 土木建 設業鉄川組設立。明治 41 年（1908）日本建築学会入会（準員）。與助は大 正 2 年 12 年（1913～1923）魚目村村会議員を務め、昭和 19 年（1944） は鉄川組を第一土建会社に統合し、昭和 24 年 (1949) 鉄川工務店に名称を 変更している。昭和 34 年（1959）７月は建設大臣表彰、11 月は黄授襄章受 章、昭和 42 年 (1967）11 月は勲五等瑞宝章を受章し、建築家として評価 を受けている。與助夫妻は、晚年は喜一郎氏と同居し、昭和 51 年（1976） 7 月 5 日横浜市にて没している。このような鉄川與助の建築経歴について は、『私たちの歩み 一株式会社鉄川工務店経歴書一』（以後『鉄川工務 店工事経歴書』）や、與助本人からの聞き取りにより一部が明らかにされ ているが、その他、筆者等の研究には、與助の五男鉄川喜一郎氏の協力の もと、戸籍簿、位牌、および菩提寺である玩海寺の確認により裏付けされ たものである。なお、既往の研究では「鉄川與助」の漢字表記を「鉄川与 助」としているが、本研究では戸籍に基づいて「鉄川與助」と表記する。

2）喜田信代, 羽深久夫 : 鉄川與助の明治期の建築経歴と桐古天主堂の請負内 容, 日本建築学会計画系論文集第 566 号, pp. 161 167, 2003.4。喜田信代, 羽深久夫, 本間博文: 冷水天主堂における鉄川與助の請負内容, 日本建築学 会計画系論文集第 568 号, pp. 133～139，2003．6。喜田信代, 羽深久夫, 本 間博文: 奈摩内天主堂における鉄川與助の請負内容, 日本建築学会計画系論 文集第 578 号, pp. 147 154, 2004. 4。喜田信代, 羽深久夫, 篠野志郎：今 村天主堂建築工事における九州地方の建築建職人・鉄川與助による施工管 理の実態, 日本建築学会計画系論文第 650 号, pp. 947 954, 2010.4。喜田 信代, 羽深久夫 : 旧長崎大司教館における建築工事の実態, 日本建築学会計 画系論文集第 703 号, 2039-2049, 2014. 9。喜田信代, 羽深久夫 : 明治 39 年 に行われた桐古天主堂改修工事の内容, 技術報告集, 2015. 10 掲載予定。

3）直営は、建築主が工事を元請業者に依頼せず、自ら労務、材料、施工機械 類の調達と施工管理を行うことをいう。明治初期の洋風官庁建築がこの方 式によって行われた。彰国社編：建築大辞典 第 2 版（普及版）, 彰国社, p. 1077, 1998.4。

4）請負契約については、多くの研究がなされているが、本稿では、以下の書 籍を参考にしている。一式請負は、総額確定請負ともいわれ、代価の総額 を請負代金として定める請負。彰国社編：建築大辞典 第 2 版（普及版）, 彰国社, p. 86, p.932, 1998．4。脇山広三 : 建築施工, 実業出版株式会社, 廣済堂, p. 13, 2004.2。

5）実費報酬加算式請負については、多くの研究がなされており、その呼称も 実費報酬加算式（北村正光：明治工業史 建築編（上），龍渓書舎, pp. 252-256, 1994. 11）、実費報酬加算式施工契約制度（稲垣栄三：日本の近 大建築その成立過程, 鹿島出版社, p. 201, 1996. 6) 、報酬加算式建築施工 契約制度 (山下寿郎: 報酬加算式建築施工契約制度, 彰国社, pp. 3-4, 1966. 7)、実費清算（関建世: 近代日本建築学発達史 復刻版第 3 編施工, 文生書 院，p. 407，2001. 12）、実費清算方式（博物館明治村編：明治村建造物 移築工事報告書（6）（重要文化財旧三重県庁舎）, 博物館明治村編, 1990 . 3）とされている。実費報酬加算式は、工事の施工者は注文者の委任を受け、 注文者に代わって工事を施工し、これに要した費用は、その都度注文者よ り交付を受け、工事の進捗を図るものである。
6)『証明願』には、3 種類の証明項目がある。その 1 は、鉄川與助はカトリ ック教会建築技師となるため、明治 33 年から 6 年間、佛人宣教師 A. ペ ルー師に建築設計学を、ドロ師に建築構造学の個人教授を受けていたこと を、カトリック教会司祭の中田藤吉が証明している。その 2 は、明治 39 年 3 月から昭和 25 年 10 月の間の 44 件で、その内主なカトリック関係建築は 40 件の主なカトリック関係建築工事（明治時代 8 件、大正時代 10 件、昭 和時代 22 件）の証明で、カトリック司教代理の古川重吉が証明している。 その 3 は、その他の建築工事 4 件（奈留島村役場漁業組合事務所、奈留島 避病舎、魚目小学校、得雄寺）の工事実績の証明で、それぞれの施主が証 明している。『証明願』で証明されている日付、昭和 25 年 8 月から 12 月 は、 1 級建築士制度が取り入れられた時期と考えられ、『証明願』はそれ に併せて取得されたものと考えられる。喜田信代, 羽深久夫：『証明願』 における鉄川與助の建築経歴, 日本建築学会大会学術梗概集, pp. 353 354, 2002. 8。

7）『鉄川工務店工事経歴書』（『私たちの歩み 一株式会社鉄川工務店経 歴書一』, 鉄川工務店, 1968. ) は、鉄川與助の主な経歴と、明治 39 年 (1906) の鉄川組創業から昭和 42 年 (1967) 10 月竣工までの 355 件の工事実績が、 発注者・施工場所・工事名・設計施工の別・構造・用途・竣工に分けて整 理されている。なお、『鉄川工務店経歴書』には、発行所、および発行年 は記載されておらず、長崎電通で作成したと伝えられている。しかし、昭 和 42 年（1967）10 月竣工までの工事実績が記載されていることから、こ の後の発行と捉えられる。なお、與助は、昭和 42 年 (1967) に勲章を受け ていることから、これに併せて作成されたと推測される。そこで、本研究 では昭和 43 年 (1968) 発行としている。

8）「天主堂既設届」（明治33年/1900）の天主堂名は「聖ペトロ堂」であり、 現在の教会名は「桐カトリック教会堂」（昭和33年/1958）である。

9）『支払伝票』は、表紙は一部破損又は全部が久損しており、寸法は（縦 $130 \times$ 横 $187 \times$ 厚 $8 \mathrm{~mm}$ m) で 1 冊に 100 枚が綴じられている。右側（縦 130 ×横 $53 \times$ 厚 $8 \mathrm{~mm}$ ） は「第 號、金、右金御渡被下度候也、年月日、殿」 と印刷され、ミシン目が入り切り離せる様式である。左側（縦 $130 \times$ 横 138 $\times$ 厚 $8 \mathrm{~mm}$ ）は控で「年月日、第 號、金、姓名、摘要」と記されている。 伝票の控部分の最初の頁には、鉛筆で、時系列に(1)から(11)の番号と、「司 教舘」と記され、日付、支払先、支払目的が記されていることから、司教 館工事の工事費が精算されていると考えられる。「小切手」に類似してい るが、金融機関名や小切手の振出地が記入されていないため、「小切手」 ではない。なお、「支払伝票」とは、書類の整理上、筆者がつけた名称で ある。

10）「書付」は、書類整理の都合上、筆者がつけた書類名である。「書付」 には、工事項目と人工、および請負金が記されている。

11）天井改修工事の依頼があった旧暦明治 39 年 1 月 14 日は、新暦では 2 月 7 日である。竣工とは明記していないが、工事に関する記載は旧暦 11 月 10 日（新暦の 12 月 25 日）迄である。

12)『手帳』(1)と『手帳』(3)には、ほぼ同じ内容で書かれた「書付」が挟み 込まれている。読み下しは、『手帳』(3)「「書付」を用いているが、これ には後日書きこまれたと思われる悪戯書きがあることから、写真は、『手 帳』(1)のものを用いている。

13）空前の工事とは何を差すのかは、詳細には記載されていないが、空枠や、 空の框、空の建具の下枠などの空周りの工事と考えられる。

14）宿老。(1)長年経験を積んで熟練した老人。藤堂明保編：学研漢和大辞典, 学習研究社, p. 362, 1978．3。「寛文 5 年 $(1628)$ 、キリス卜教徒の入島を 禁止する御札が立てられ、（中略）身元の知れない者には、いっさい宿を 貸さない (後略)」。内藤莞爾 : 五島列島のキリスト教系家族, 弘文堂, p. 18，1979．2。宣教師時代に宿を提供しお世話をしていた人で、教会のリ ーダーの役割。現在では経済評議員と呼ばれ、主任司祭を助け教会のため に尽力する立場である。（長崎カトリックセンターからのご教示による）。 15）この他に、7月 11 日に「濱口氏宅にて $\square \square$ 行費 100 円」と受取金 100 円 があるが、これは旅費および調査費で、桐古天主堂改修工事の費用ではな い受取金と考えられることから、桐古天主堂改修工事費には含めない。

16）閏 4 月 30 日の支払 43 円 34 銭は（祖父追膳の節 冷水杉代 93 銭の所 52 円渡し 40 円と 3 円合して勘定済）で、冷水杉代も勘定されている。

17） 6 個の硝子障子の価格は、「1 一円三十四銭、2 一円三十四銭、3一 円二十六銭三厘、 4 一円十銭、 5 八十三銭、6 一円十二銭」と記されて いる。

18）幕末、外人建主と日本人職人との間に交された建築工事契約書（英文） は、1861年 5 月 13 日に、Francis. A Groom と小山良輔との間に交された 
工事契約書で、11 項目の契約事項が記載されている。ここでは、全てのド ア・空・鎧戸と、鍵・ヒンジ・ボルトと硝子などの材料は、F. Groom 氏よ り提供されるとの契約である。山口光臣：長崎の洋風建築, 長崎市教育委 員会，pp. 90-92，1967。3。

19）チュウノウとは何か、現時点では不詳である。

20）善吉は、桐古天主堂改修工事で大工として従事している。喜田信代, 平井 聖, 本間博文, 羽深久夫 : 桐古天主堂 - 冷水天主堂 - 奈摩内天主堂 - 今村天 主堂における関与した人々と鉄川與助の役割, 2005 年度日本建築学会大会 学術梗概集 (近畿),pp.199〜200, 2005.9。

21）この 8 円 40 銭については、3 月 30 日の前に記載されていることから、 当該欄に記載している。

22）湯川幸太は家族ではないことから、お盆である 8 月 14 日に 5 円渡された ものと考える。

23）宮原の役割については、現段階では不詳である。

24）木挽は、竣工月の 11 月にも柱や壁板の工事をしているが、桐古天主堂改 修工事費としての精算は確認できない。引き続き、冷水天主堂新築工事も 同じ木挽が従事していることから、次の工事と通算して精算された可能性 が考えられる。

25）木挽は、「木挽の作業場は厘場（りんば）、その手間賃は厘代（りんだ い）と称され、大工手間貨より高いのを原則とした」（彰国社編：建築大 辞典第 2 版, 彰国社, p. 582, 1998.4）とあることから、木挽の食事は鉄 川組職人とは別に賄われたと考えられる。

26）「縄本船 $\square$ の内」は内金と思われるが、「縄本船 $\square 」 は$ 不詳である。

27） 4 月 1 日の丸尾行き費用 10 円、 7 月 28 日の父と與助の旅費 11 円は、旅 費としては額が大きいことから鉄川組に渡寸費用が含まれていると考えら れるが、ここでは裏付けがとれないことから、記載の通り、旅費として扱 う。

28) 3 月 21 日の支払の大阪書店前金は、大阪市東区唐物町四丁目石川書店に、 『議事録ノ二巻』、『木造洋館詳細雛形集 第 $1-5$ 輯』（三橋四郎編 ; 高 橋仁太, 1900 年）と、『木造洋館雛形集 上下』（吉原米次郎編；建築書 院, 1897 及び 1898 。）三冊を代金 5 円 25 銭で注文している。

29）「心配料」とは、お世話になった人たちへの心付けと思われる。

30）工事着手前や、丸尾の祭、8月の盆などには芝居見物など娛楽費の出費 があり、組の仕事にメリハリをつけていたものと考えられる。

31) 桐古天主堂改修工事の後に着手寸る冷水天主堂新築工事 (明治 40 年/1907) では、最初に大工道具 1 年分を渡している。

32）受取金は 6 円 34 銭多くなるが、この金額は工事費の受払で許容範囲と 考えられる。

33）同じ期間の受取金は、この他に、4月 16 日の杉山での 40 円と、 5 月 3 日 の 51 円の 91 円あるが、與助の勘定に含まれていない理由は不詳である。

34）與助は、「第 1 回目勘定」、「再度目勘定」と「その他」としているが、 整理の都合上、筆者は「第 1 回目勘定」、「第 2 回目勘定」、「第 3 回目 勘定」としている。

35）仲裁とは、何らかのもめ事に対する解決の方法といえる。冷水天主堂新 築工事は煉瓦造と木造を検討した上で木造に決まった経緯がある。「木挽 の不足は神父が補う」との記載から、請負金のうち、木挽賃に相当する費 用は足りないことが最初から分ったらえで、継続して教会建築工事を請負 なかで、木婏賃の不足は補うとしたものと推測されることから、そのまま 記載している。

36）決算金額は與助の史料からは不詳であるが、125 周年記念誌編集委員会 編：今村信徒発見 125 周年記念誌, 今村カトリック教会, p. 96, 1992. 11 には、凡 3 万円とある。これは基礎工事の使工事によるものと考えられる。

37）『雑費記入簿』は、文字が擦れて読み取りできない箇所もあることから、 合計金額は、3,771 円を超すものと考えられる。

38）與助は、史料に「地中室」と表記しているが、司教館地下室のことだと 考えられることから、本稿では地下室と表記する。

39）田中豊太郎編（辰野金吾、妻木頼黄博士、三橋四郎の閲覧）：和洋建築 工事仕様設計實例 上・下：工業書店建築書院，1905、および 1908 では、 工事項目を、それぞれ数字で表している。支払伝票には「一から十六」の 漢数字が書き分けられている。これは、司教館工事における工事項目をあ らわしていると考えられ、與助は、既に、この文献を参考にしていると考 えられる。

40）與助の妻卜サの費用は、松江商店の買物代金である。トサは、桐古天主 堂改修工事以降、工事現場に同行して賄いなどに従事していることから、 それらの費用と考えられる。
41）明治 20 年（1887）当時、建築学会会員の新築工事における設計者と請負 者の状況が記されており、それによると一式請負は、東京、仙台、富山、 宇都宮、大阪、京都、滋賀、名古屋、熊本と全国に拡がっている。『建築 雑誌』（18870928）雑報, 本文 pp. 140-141。

42) 英吉利法律学校（中央大学の前身）（明治 20/1887 年 7 月〜明治 $22 / 1889$ 年 12 月）は、辰野金吾の設計で、日本最初の工事請負契約書をつくった。 本文の抜粋は、以下の文献の p. 69 から転載している。清水建設百五十年 史編纂委員会 : 清水建設 150 年史, pp. 68-69, 1953。11。

43）実費報酬加算式の事例は、長野県松本市の開智学校（明治6年/1873）と、 三重県津市にあった旧三重県庁舎（明治12年/1879）などが明らかにされて いる。長野県松本市の開智学校の工事費明細の工事明細書については、重 要文化財旧開智学校本館移転修理工事事務所編 : 重要文化財旧開智学校本 館移転修理工事報告書, 松本市教育委員会, 1965.3がある。参考資料の1。開 智学校建築関係史料、2. 明治8年立石清重提出の開智学校新築仕様帳、 3 . 明治29年風水害修理見積書並びに請負証の詳細な記録があり、実費精算方 式の実態が判る。重要文化財旧開智学校本館移転修理工事事務所編 : 重要 文化財旧開智学校本館移転修理工事報書, 松本市教育委員会, 1965. 3。旧三 重県庁舎は、大工の家業を継いだ清水義八 (1846-1914) が、明治9年 (1876) 10月、三重県庁日給雇となり、その後、県営繕関係の仕事に従事している。 三重県営繕資料等に含まれる、2「県庁新築山切下費清算帳」、3「県庁新築 仕様経」、4「県庁新築補足受渡簿」、5「県庁補足金高簿」、6「県庁新築別 途官金受渡簿」、以下・・・、23「県庁舎建築工事一件」までの書類と、 「県庁御新築清算帳」の書下し、ならびに、「明治十一年ヨリ全十二年二至 縣廳新築仕様書綴 営繕係」以下の写真資料から、詳細な工事の内訳、伺 高、清算高、請負人と出納簿や、稟議などから、明治初期における実費精 算方式の実態と提出書類の内容が判る。博物館明治村編：明治村建造物移 築工事報告書 (6)（重要文化財旧三重県庁舎），博物館明治村編，1990．3。

44）魚目水産学校新築工事の史料は、「魚目水産学校新築仕様設計書」、な らびに「魚目水産学校断面図」と「魚目水産学校平面図」である。また、 若松村立尋常小学校新築工事の史料は、「若松村立尋常小学校新築工事仕 様書」、ならびに「若松尋常小学校新築平面図」と「教員住宅平面図」、

「若松尋常小学校新築工事費豫算書仕譯書」、「若松村立尋常小学校一 式請負人心得書」である。いずれの書類にも署名・押印はないことから写 と捉えられる。工事は、一式請負の施工と考えられるが、書類内容からは、 工事費の受払については不詳である。

45）物価の変動に関しては、近代米価表を参考にしている。それによると、 明治元年（1868）の物価指数を 100 とすると、明治 39 年（1906）は 273、 大正 5 年 (1916) は 538 である。 


\title{
CHARACTERISTICS OF CONSTRUCTION COST RECEIPTS AND PAYMENTS FOR THE RENOVATION OF THE KIRIFURU CHURCH IN 1906
}

\author{
Nobuyo KITA* and Hisao HABUKA** \\ * Grad. Stud., Graduate School of Design, Sapporo City University, M.A. \\ ** Prof., Graduate School of Design, Sapporo City University, Dr. Eng.
}

The renovation of the Kirifuru Church in 1906 was an extension work associated with the repair of the ceiling of the church building as requested by the Roman Catholic Church. Yosuke Tetsukawa discussed the details of the construction work with the missionary in charge, to whom the construction schedule and estimates were presented for budgetary approval.

Yosuke negotiated with mountain owners and purchased timber with cash. He placed orders following which the church made the payment for material such as bricks, roof tiles, white ash, stones, ironware, and glazed sliding door. Prior to the commencement of the construction work, Yosuke provided tools to craftsmen affiliated with Tetsukawa Gumi. The church funded the wages that Yosuke paid to the bricklayers, plasterers, and stone masons.

The renovation was estimated to cost JPY 395.60, including the construction work for the altar. The amount received was JPY 385.60, of which JPY 379.56 and 4 rin were used to pay wages for craftsmen, as well as for meal, travel, and miscellaneous expenses. The church made additional payments toward material and tool costs, either directly or through Yosuke. The cost of the renovation work was the sum of the total amount paid, i.e., JPY 776.82 and 3 rin plus the material and other expenses the church paid for directly. Yosuke determined the contract amount based on carpenter and sawyer wages. Cedar timber was purchased on accounts receivable on behalf of the church for the construction of the Hiyamizu Church (1907). Furthermore, the church made direct payments for the roof tiles, hypophosphorous acid, and emery powder, as well as roofers' remuneration. The carpenter and sawyer wages were estimated at JPY 1,560. The construction costs were classified as "Your Payment" and "Our Payment" or "Construction Purposes" and "Private Purposes" for the construction of the Namauchi Church (1910). The "Your Payment" account consisted of material and tool costs as well as craftsmen wages, and the "Construction Purposes" account consisted of meal and miscellaneous construction costs. The other two accounts were considered to have been for Yosuke's personal expenses.

An unforeseen situation arose during the construction of the foundation, which resulted in additional construction work, as well as secondary reviews of material for the new construction of the Imamura Church (1913). The contract amount was JPY 4,362.50 for the carpenter and sawyer wages. Yosuke paid for timber and roof tiles that were purchased directly from vendors; all other expenses were paid for directly by the church. Wages for stone masons, bricklayers, and plasterers were paid through Yosuke. He verified the "payment slip" as an agent for the person in charge of the church's construction work, and the church made payment for material, construction work, wages, deliveries, transportation contracts, etc.

The payment method adopted by Yosuke for the Kirifuru Church renovation work-determining the contract amount for Tetsukawa Gumi, his direct intermediary role in payments for timber negotiations and purchases as well as craftsmen wages, and the Church's direct payments for other material costs-was also adopted for construction of other new churches thereafter. 